\title{
Study of Massive Floating Solar Panels over Lake Nasser
}

\author{
Moustafa Elshafei $\mathbb{D}^{1},{ }^{1}$ Abdelrahman Ibrahim, ${ }^{1}$ Amr Helmy, ${ }^{2}$ Mostafa Abdallah, ${ }^{3}$ \\ Amgad Eldeib, ${ }^{3}$ Moustafa Badawy, ${ }^{4}$ and Sayed AbdelRazek ${ }^{5}$ \\ ${ }^{1}$ Zewail City of Science and Technology, 6th October City, Giza 12578, Egypt \\ ${ }^{2}$ Nanotechnology Program, Zewail City of Science and Technology, Egypt \\ ${ }^{3}$ Renewable Energy Program, Zewail City of Science and Technology, Egypt \\ ${ }^{4}$ Environment Engineering Program, Zewail City of Science and Technology, Egypt \\ ${ }^{5}$ Mechanical Engineering Department, Misr University of Science and Technology, 6th October City, Giza 12578, Egypt \\ Correspondence should be addressed to Moustafa Elshafei; moelshafei@zewailcity.edu.eg
}

Received 15 October 2020; Revised 8 February 2021; Accepted 12 March 2021; Published 13 April 2021

Academic Editor: Hao Wu

Copyright (c) 2021 Moustafa Elshafei et al. This is an open access article distributed under the Creative Commons Attribution License, which permits unrestricted use, distribution, and reproduction in any medium, provided the original work is properly cited.

\begin{abstract}
Recently, the technology of floating photovoltaic panels has demonstrated several advantages over land installations, including faster deployment, less maintenance cost, and higher efficiency. Lake Nasser is the second largest man-made freshwater lake in the world with a surface area of almost 5000 square $\mathrm{km}$. Being in one of the hottest areas in the world, evaporation of water causes loss of very precious and scarce resources: freshwater. Fortunately, the lake is also located in a very rich area in solar energy. This paper presents a study to utilize Lake Nasser's surface for massive production of solar energy, while significantly reducing the loss of water by evaporation from the lake surface. The project has the potential to be one of the largest producers of low-cost clean electric energy in the world for Europe and the Middle East and North Africa (MENA) region, especially with the ongoing efforts to connect the North African countries with the European super power grid. The study shows that the first phase of the project is expected to deliver about $16 \%$ of European need of electricity and save about 3 billion $\mathrm{m}^{3}$ of freshwater. The subsequent phases will provide low-cost green energy to replace the combustible fuels in Europe by 2045, while saving up to $10-12$ billion $\mathrm{m}^{3}$ of freshwater lost by evaporation from Lake Nasser.
\end{abstract}

\section{Introduction}

The European Union (EU) has established environmental protection and migration to renewable energy as strategic goals [1]. The European revised renewable energy directive 2018/2001/EU has set a target for the renewable energy (hydropower, solar, and wind) share to meet or exceed $32 \%$ by $2030[2]$.

In 2016, Europe consumed almost $3100 \mathrm{TWh} / \mathrm{y}$ [3]. The combustible sources accounted for $48.7 \%$ of the generated electricity. The wind energy and solar energy accounted for $9.7 \%$ and $3.5 \%$, respectively. However, the recent decline of the land wind power generation in Germany sparks concerns about the potential of wind power in meeting the European environmental goals [4].
A study conducted by Fraunhofer Institute for Solar Energy Systems (ISE) examined the technical potential of deploying solar technologies in North Africa and its ability to meet the European need for electricity [5]. The report estimated electricity demand of North Africa and Europe to be $5850 \mathrm{TWh}$ in 2050 and proposed to establish a super electric power grid to integrate the solar energy production in North Africa with Europe.

Egypt has already embarked upon a number of largescale solar electricity projects. For example, the Benban project, the 4th largest solar power plant in the world, is aimed at establishing a solar park over 37.2 square kilometers, in the southern part of Egypt. The Benban project has the potential to produce almost $1.7 \mathrm{GWp}$, with a total annual production capacity of 3.8 TWh [6]. 


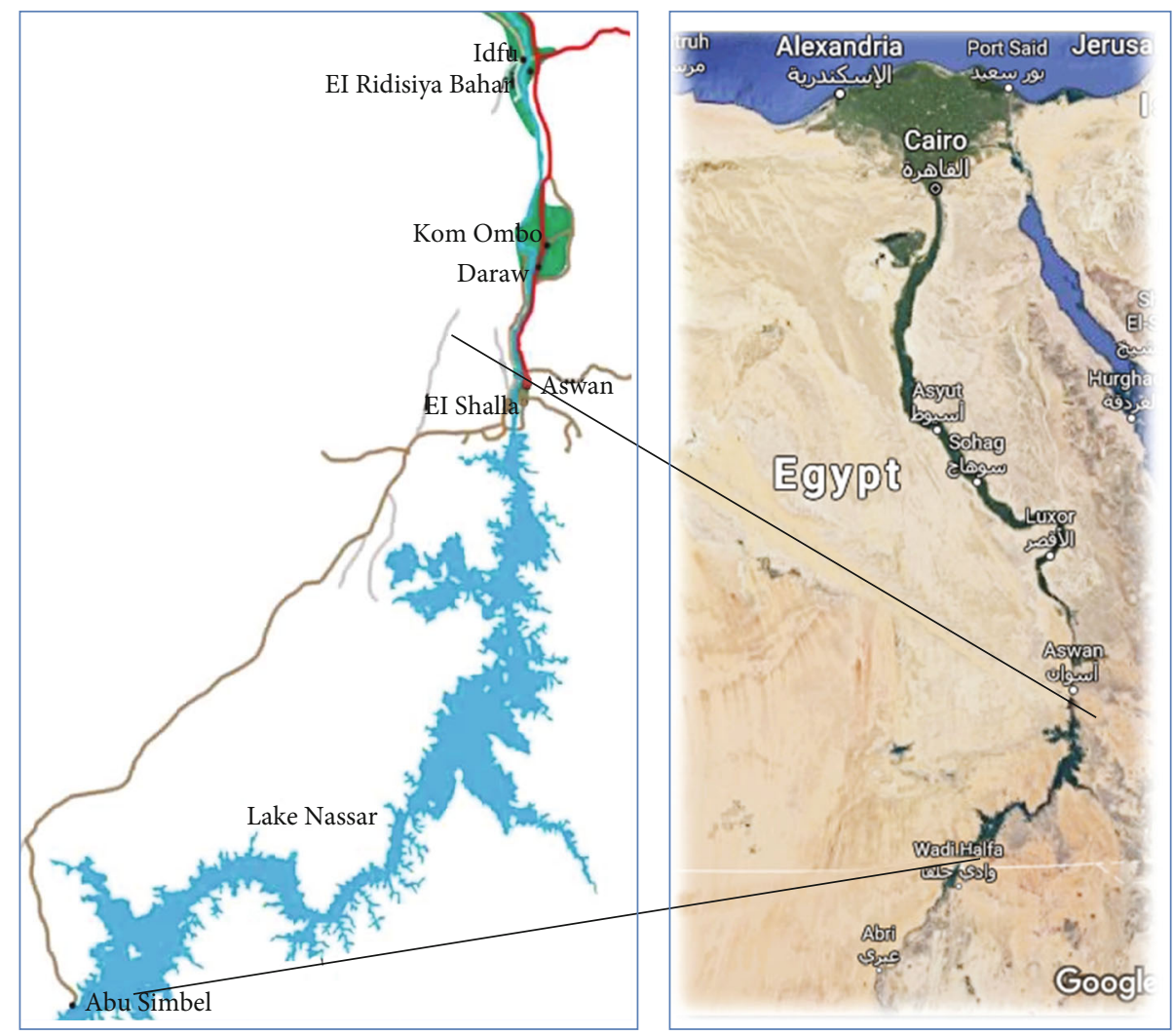

Figure 1: Location of Lake Nasser in Egypt [12].

Recently, the floating photovoltaic (FPV) panels have been demonstrated in several areas worldwide $[7,8]$. The FPV technology promises to provide solar energy cheaper than PV land installation because it has higher efficiency than land installations due to the cooling effect of the water mass. FPV installations are also faster to deploy and require less cleaning compared with the cleaning/maintenance cost for land installations in dry dusty desert areas [9].

Lake Nasser in Egypt has a surface area of about $5000 \mathrm{~km}^{2}$. It is located in one of the richest areas in solar energy in the world. In this paper, we present a study for a massive deployment of floating PVs over Lake Nasser to provide low-cost green electricity for Europe and North Africa, integrated with the European-North Africa super grid [5]. The coverage of the lake surface could also save as high as 12-16 billion $\mathrm{m}^{3}$ /year of evaporated water, enough to alleviate some of the impacts of the Ethiopian renaissance dam on Egypt. The presented study is aimed at providing a comprehensive account of the key factors to help all the interested parties to develop the best economical and engineering strategies of such a terascale project, and it is to be the starting point for further economic, engineering, social, and environmental studies. The next section provides a review on Lake Nasser's geography, water hydrology, and climatology factors. The following sections cover water evaporation problem and water saving, solar energy potential, and the estimated cost based on the current commercial technology of PV and the technology trends. Next, we discuss various options for energy storage technologies and mitigation of possible impacts of the project on fishery and ecology.

\section{Lake Nasser}

Lake Nasser resulted from the Egyptian High Dam construction, during the period from 1958 to 1971 [10]. The lake is the High Dam's reservoir, extending roughly from $21^{\circ} 12^{\prime}$ $32^{\prime \prime} \mathrm{N}$ and $30^{\circ} 40^{\prime} 32^{\prime \prime} \mathrm{E}$ in Sudan to $23^{\circ} 58^{\prime} 25^{\prime \prime} \mathrm{N}$ and $32^{\circ} 51^{\prime}$ $43^{\prime \prime} \mathrm{E}$ in Egypt [11]. The Egyptian part is known as Lake Nasser (see Figure 1), while the part in Sudan is known as Lake Nuba. However, $83 \%$ of the lake water exists on the Egyptian side. The long reservoir has 100 side major arms or bays called Khors; their number on the eastern shore is higher than that on the western shore. The reservoir is surrounded by rocky desert terrain. To the west is the great Sahara Desert, while the Eastern Desert side stretches to the Red Sea, with several shore side plateaus of 50-100 meters above the water level. The average width of the lake is $12 \mathrm{~km}$, the average depth is 25 meters, and it is as much as 107 meters (350 feet) deep at the dam's face [11].

2.1. Hydrology and Water Management. The knowledge of the seasonal and yearly variations in the surface level of Lake Nasser is essential for proper design of the mooring systems of FPVs. The total capacity of the reservoir is reported to be about 162 cubic $\mathrm{km}$ [11], consisting of a dead storage of 31.6 cubic $\mathrm{km}$ (85-147 $\mathrm{m}$ water level above sea level (ASL)), the active storage of 90.7 cubic km (147-174 ASL), and the emergency storage for flood protection which is 41 cubic km (175-182 m ASL); see Figure 2. The water year starts on August 1st, at which the water level is kept at $175 \mathrm{~m}$ ASL. When the water level upstream reaches an elevation between 


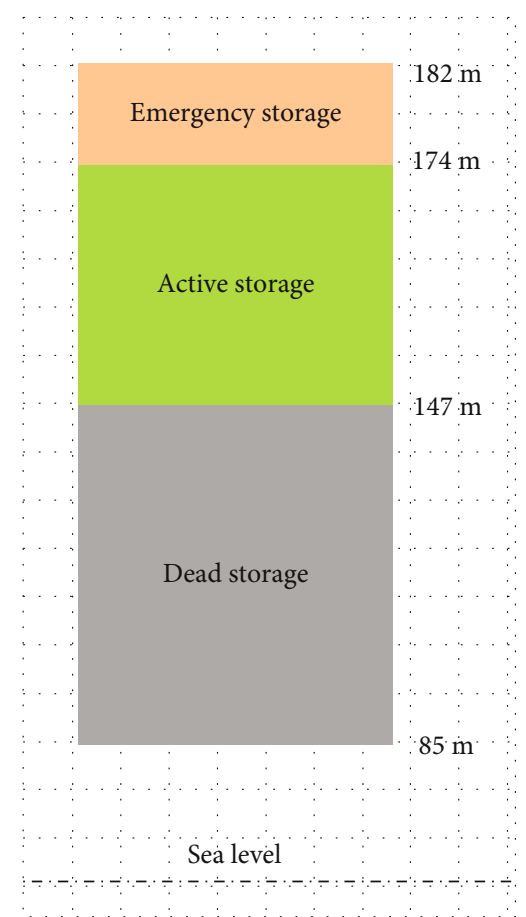

FIgURE 2: The total capacity of the Lake Nasser reservoir.

$178 \mathrm{~m}$ and $183 \mathrm{~m}$, excess water is directed to a dipped landform known as Toshka depression and if necessary to emergency spillways. The maximum retention at $180 \mathrm{~m} \mathrm{ASL}$ is obtained in November. The water levels then continue to decrease from January to July as water is discharged for normal nation's consumption.

According to data from the Ministry of Water Resources, the relationship between both the water surface area and the perimeter of the lake versus the water level is depicted in Figure 3.

The surface area $A_{\mathrm{s}}$ of the lake is related to the water level by the empirical formula

$$
A_{\mathrm{s}}=22.296 e^{-\left(0.0311\left(W_{\mathrm{L}}\right)\right)} \text {, }
$$

where $W_{\mathrm{L}}$ is the average monthly water level [13].

Several studies were conducted using satellite remote sensing data to assess the changes in the water level $[14,15]$ and water volume [16-18]. These studies helped as well in estimating the annual water loss by evaporation from the lake. The mean yearly variation in the water surface level based on records from 1992 to 2018 is about 6 meters [15], as shown in Figure 4.

2.2. Climate. The average minimum and maximum temperatures at Aswan city (about $7 \mathrm{~km}$ north of the High Dam) are shown in Figure 5. The figure shows that the average maximum temperature in summer is $42^{\circ} \mathrm{C}$ degrees while the average minimum temperature in winter is about 10 degrees [19]. Clearly, the selection of the construction material and the design of the electronic components for the FPVs need to consider the full range of the environmental temperature in the Lake Nasser region.
A study of climate records of the Aswan region from 1955 to 2013 reveals no significant changes for the climate due to the construction of the High Dam. It also concluded that the temperature at $2 \mathrm{~m}$ high is the main contributing factor to evaporation losses [20].

The wind speed has a mild monthly average of about 3.8 meters/s, as shown in Figure 5, which is about $13.7 \mathrm{~km} / \mathrm{h} \mathrm{[20].}$ A summary of seasonal statistics of wind speed is shown in Table 1. The wind direction is mainly north as shown in Figure 6.

The wind speed and direction are important factors in the design of tilted PVs and the design of the power and communication towers and for estimating the stress on the mooring systems. The rainfall in Lake Nasser is only a few millimeters per year [21].

On the other hand, the average percentage of the sky covered by clouds experiences relatively small seasonal variation over the year. According to [22], the sky is mostly cloudy $25 \%$ of the time in December and clear, mostly clear, or partly cloudy $75 \%$ of the time. The clearer period of the year in Aswan is from mid-May to about mid-July. June is usually the clearest month of the year.

2.3. Water Temperature. In general, air and water temperatures increase from north to south [23]. The highest water temperature, $34.1^{\circ} \mathrm{C}$, was recorded at Abu Simbel in summer; the lowest, $16.2^{\circ} \mathrm{C}$, at the High Dam in winter [24]. The water temperature in the northern part of the lake is about $27^{\circ} \mathrm{C}$ in August, 22-23 degrees in November and March, and 16-17 degrees in February. The temperature also decreases with depth. At a depth of greater than 30 meters, the temperature remains between 16 and $20^{\circ} \mathrm{C}$ year-round.

Knowledge of water temperature is important in estimating the efficiency of the FPV. Satellite's images were used to infer the surface water temperature [17]. It was found that the surface water temperature depends on the depth of water. A satellite image taken in March shows that in the middle of the lake (high depth area), the temperature varies between 12.4 and $18.9^{\circ} \mathrm{C}$, in less depth near the shores it was found to be in the range of $18.9-21.5^{\circ} \mathrm{C}$, while in shallow areas the surface water temperature was between 21.5 and $25.86^{\circ} \mathrm{C}$.

\section{Water Evaporation}

The Egyptian quota from the Nile River is limited to be about 55 billion $\mathrm{m}^{3} / \mathrm{y}$ and is expected to decrease due to the increasing demand for water by other Nile basin countries [25]. According to an Egyptian government report [26], the total population of Egypt increased from 22 million in 1950 to around 85 million in 2010 (currently, it reached almost 100 million). The population is likely to reach between 120 and 150 million by 2050. Egypt has reached a state of water poverty where the available quantity of water is imposing limits on its national economic development [27]. As an indication of water shortage, the threshold value of $1000 \mathrm{~m}^{3} /$ capita/year is usually used as an indicator. Egypt has already gone below this threshold since the nineties, and it is expected to cross the threshold of an absolute scarcity of $500 \mathrm{~m}^{3} /$ capita/year by 2025 [26]. 


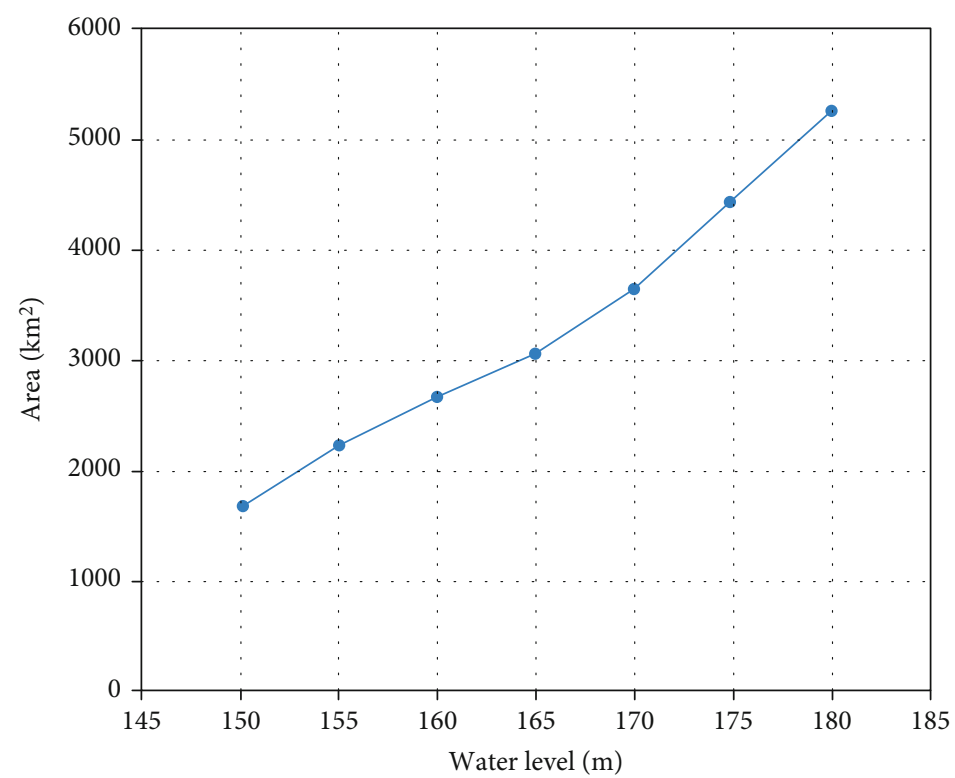

FIGURE 3: Variation of Lake Nasser surface area versus water level [13].

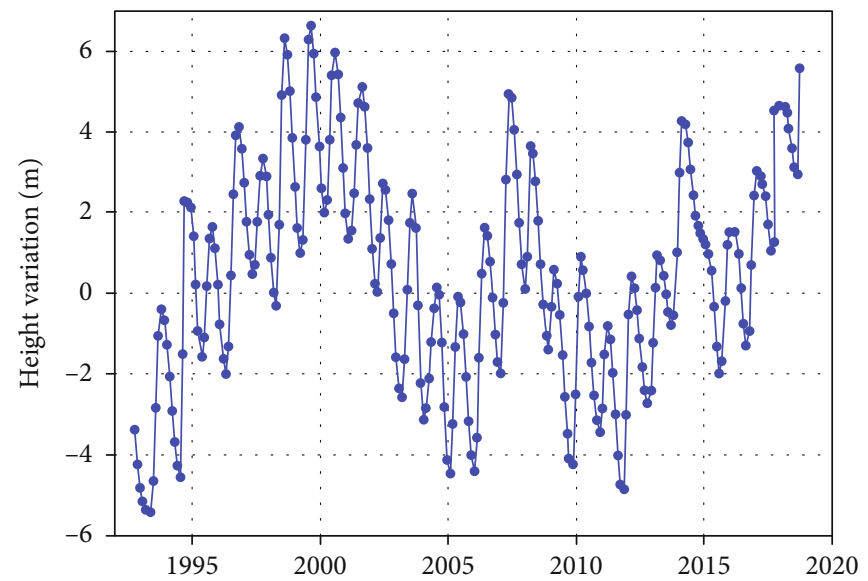

Figure 4: Variation of the Lake Nasser water levels from 1992 to 2018 [15].

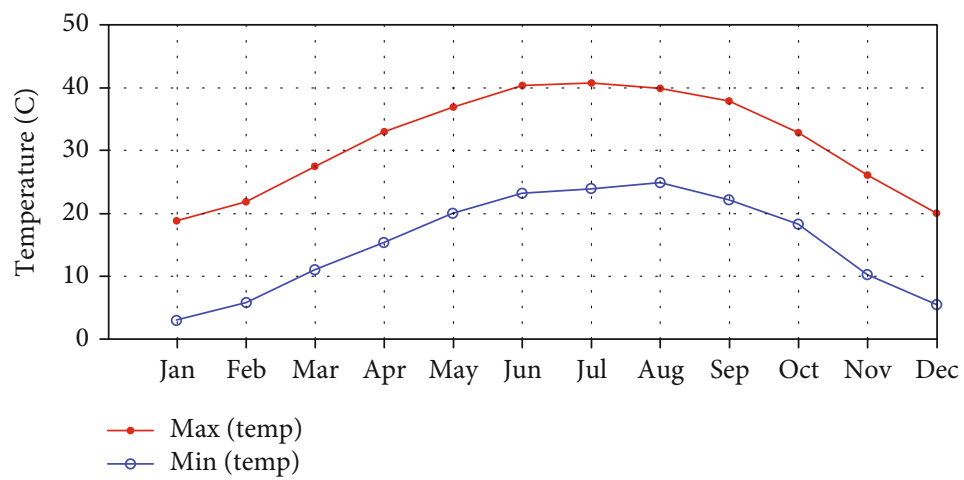

Figure 5: Average monthly temperature variations at Aswan [19].

Egypt is stepping up efforts to address water scarcity at a high cost [28], pledging EGP 900 billion Egp ( $\$ 51$ billion) for a national water management plan over 20 years.
In continuing efforts to fulfill its growing water needs, Egypt is set to build the largest seawater desalination plants in the world. The total existing desalination capacity is 
TABLE 1: Statistics of wind speed based on 1995-2013 data [20].

\begin{tabular}{lcccc}
\hline \multirow{2}{*}{ Wind } & $\begin{array}{c}\text { Summer } \\
\text { NW }\end{array}$ & $\begin{array}{c}\text { Autumn } \\
\text { NW-NE }\end{array}$ & $\begin{array}{l}\text { Winter } \\
\text { N-NE }\end{array}$ & $\begin{array}{l}\text { Spring } \\
\text { N-NE }\end{array}$ \\
\hline Wind speed $2.1-3.6 \mathrm{~m} / \mathrm{s}$ & $41.2 \%$ & $15.7 \%$ & $39.2 \%$ & $47.1 \%$ \\
Wind speed $3.6-5.7 \mathrm{~m} / \mathrm{s}$ & $58.8 \%$ & $84.3 \%$ & $68.8 \%$ & $52.9 \%$ \\
\hline
\end{tabular}

$235,600 \mathrm{~m}^{3} /$ day. The new projects will add a total capacity of over one million $\mathrm{m}^{3} /$ day. The installed cost of desalination plants is approximately $\$ 1 \mathrm{~m}$ for every 1000 cubic meters per day of installed capacity.

On the other hand, the annual water losses by evaporation from Lake Nasser are estimated between 12 and 16 billion cubic meters [29], which is $20-30 \%$ of the Egyptian share of the Nile water. This water loss has been flagged as a serious national problem because the lake is the water bank of Egypt.

Estimation of the evaporation rate from Lake Nasser using Bowen ratio energy budget (BREB) method was proposed in [30]. Bowen ratio is the ratio between sensible heating and latent heating. Sensible heat transfer is connected with temperature difference while latent heat transfer is associated with change of states without change in temperature. The calculations were based on local meteorological and hydrological data from three floating weather stations.

The BREB evaporation rate is estimated using the following equation:

$$
E_{\mathrm{EB}}=\frac{R_{\mathrm{n}}+Q_{v}-Q_{x}}{\rho_{\mathrm{w}}\left[\lambda(1+\mathrm{BR})+c\left(T_{o}-T_{b}\right)\right]} \times \Gamma
$$

where $E_{\mathrm{EB}}$ is the evaporation rate in $\mathrm{mm} / \mathrm{day}, \rho_{\mathrm{w}}$ is the density of the evaporating water, $\lambda$ is the latent heat of evaporation $(\mathrm{J} / \mathrm{kg}), c$ is the specific heat of water, $R_{\mathrm{n}}$ is the net radiation energy, BR is the Bowen ratio, $\Gamma$ is a scale factor $=8.64 \times 10^{7}, T_{b}$ is the reference temperature, $T_{o}$ is the lake surface temperature, $Q_{x}$ is the increase in energy stored in the water body, and $Q_{v}$ is the net energy carried into the water body because of inflow and outflow of water.

The BREB monthly average of evaporation rates ranged from 3.4 to $13.3 \mathrm{~mm} /$ day, with an overall average of $7.22 \mathrm{~mm} /$ day. This estimate comes close to the adopted figure of the Egyptian Ministry of Water Resources and Irrigation of $7.54 \mathrm{~mm}$ /day. The authors also compared the BREB method with results from six conventional evaporation quantification methods.

Another study in 2012 used twenty-four satellite images during the year 2008 to estimate the maximum and minimum evaporative losses from the lake at 16.3 and 12.5 billion cubic meters per year [31].

Hassan [32] estimated the rate of evaporation from Lake Nasser using the Surface Energy Balance Algorithm for Land (SEBAL). SEBAL is an image-processing model for calculation of the evapotranspiration (ET) rate based on satellite images of the spectral radiance in the near-infrared (NIR), visible (VIS), and thermal infrared (TIR) part of the spectrum
[33]. The method was also adapted and applied for large water body in [34].

The surface energy balance equation is given by [32]

$$
R_{\mathrm{n}}-H-\lambda E=Q_{x}-Q_{v},
$$

where $R_{\mathrm{n}}$ is the net radiation $\left(\mathrm{W} / \mathrm{m}^{2}\right)$ at the water surface. $R_{\mathrm{n}}$ is estimated from Landsat TM spectral data of the lake. $H$ is the sensible heat flux, $E$ is the water mass evaporation flux, $\lambda$ is latent heat of vaporization, $\lambda E$ is latent heat flux required for evaporation, $Q_{x}$ is the increase in energy stored in the water body, and $Q_{v}$ and $Q_{x}$ are defined before. $Q_{x}$ and $Q_{v}$ were inferred from hydrological and meteorological measurement collected from three floating weather stations. Other meteorological data were also measured or inferred. The estimated evaporation rate was $6.6 \mathrm{~mm} /$ day [32].

A more recent study in 2018 [35] estimated the evaporation losses using two different techniques; the first method integrates Geographic Information System (GIS) techniques and MODIS images. The result showed that the water losses by evaporation from Lake Nasser ranged from about 12.3 to 12.9 billion $\mathrm{m}^{3}$ per year. The second method found the annual losses to be 16.3 to 17.4 billion $\mathrm{m}^{3}$ using data from MERRA images and ECMWF (ERA-Interim) [35].

Several studies proposed a variety of techniques to reduce the water lost by evaporation from Lake Nasser. A study in 2007 evaluated several methods for evaporation reduction from Lake Nasser, including floating cover sheets, similar to the one shown in Figure 7(a). The authors also proposed a new technique, where a pontoon framework is placed on the water surface, enclosing square surface areas of $10 \times 10 \mathrm{~m}$ filled with circular foam sheets, as depicted in Figure 7(b). Several options for the percent coverage and cover material were studied. They also estimated the yearly average evaporation rate to be $6.33 \mathrm{~mm} /$ day or about $2.3 \mathrm{~m}^{3}$ per $\mathrm{m}^{2}$ per year [13].

In an effort to mitigate the evaporation losses from Lake Nasser, a study in 2010 proposed disconnecting (fully or partially) some of its secondary channels (Khors) [36].

In a recent study in 2019, the author examined two schemes to compensate for the water evaporation losses, namely, weather modification and water harvesting from the air. The study estimated the evaporation losses from Lake Nasser to be in the range from 5 to $10 \mathrm{~mm} /$ day throughout the year with an average of $7.4 \mathrm{~mm} / \mathrm{m}^{2} /$ day. This evaporation loss is estimated to be $20 \%$ of the annual consumption of water by Egypt for farming, industrial, and domestic applications [37].

A brief review of the existing techniques to reduce evaporation from water surfaces was conducted in 2019. The evaporation reduction techniques were classified as physical methods, biological methods, and chemical methods [38]. Physical methods, which include floating or suspended covers, can save a large percentage of water (between 70 and 95\%); however, their capital costs are high. Biological methods, such as floating plants, windbreakers, and palm fronds, could provide a significant decrease in the volume of evaporation. However, the water drawn up and used for 


\begin{tabular}{|l|r|l|}
\hline $\mathrm{N}$ & $68 \%$ & \\
\hline $\mathrm{NE}$ & $8 \%$ & \\
\hline $\mathrm{E}$ & $1 \%$ & \\
\hline $\mathrm{SE}$ & $1 \%$ & \\
\hline $\mathrm{S}$ & $2 \%$ & \\
\hline $\mathrm{SW}$ & $1 \%$ & \\
\hline $\mathrm{W}$ & $3 \%$ & \\
\hline $\mathrm{NW}$ & $15 \%$ & \\
\hline
\end{tabular}

Figure 6: Wind direction (January 2000-December 2008) at Aswan [21].

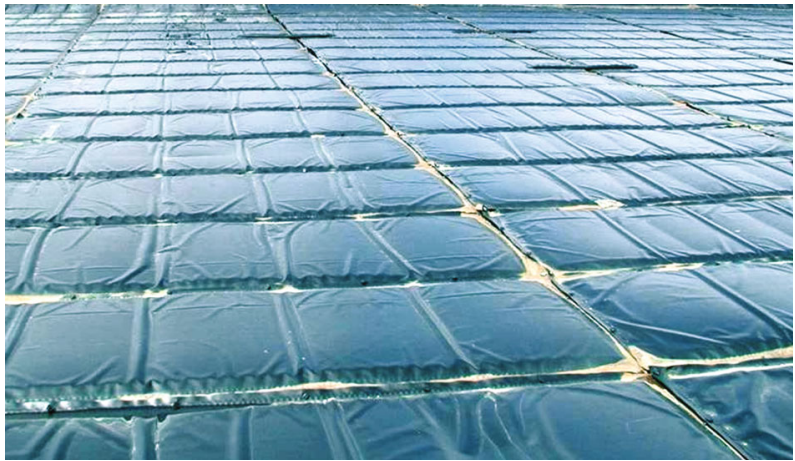

(a)

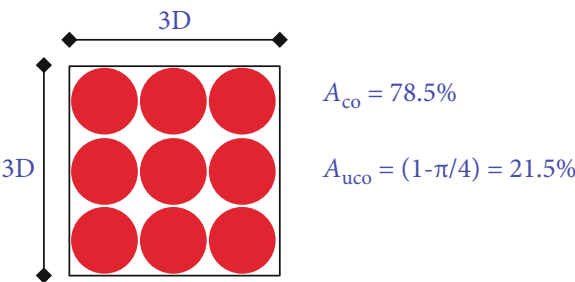

(b)

Figure 7: (a) Example of commercial coversheets to prevent evaporation. (b) Proposed circular foam sheets [13].

transpiration by plants needs to be taken into account to estimate the efficiency of using them for the purpose of evaporation reduction. Moreover, concerns for long-term ecological impacts pose some restrictions on their uses.

Chemical methods, on the other hand, have relatively low capital cost (per $\mathrm{m}^{2}$ of water surface). The fast and simple deployment methods of the chemical methods make them attractive for farm ponds and small lakes, but their effect depends on the surface condition including waves, wind, currents, and temperature. For large lakes, the maintenance costs of chemical methods could be significant, since under the action of currents, winds, and waves the chemical films can be displaced and destroyed [38].

The above evaporation studies consistently estimate the annual loss of water by evaporation from Lake Nasser to be at least $20 \%$ of Egyptian quota from the Nile River, and there is no viable solution to solve this problem.

On the other hand, it has been established in the literature that FPVs contribute to reduction of water loss by evaporation from the lakes [38-40]. For example, the study in [39] in Spain reported a theoretical and experimental analysis of covering a $4490 \mathrm{~m}^{2}$ surface reservoir with floating PVs. The study reported annual water saving of $25 \%$ was achieved, while over $400 \mathrm{MWh}$ of renewable power was generated per year. A review [40] of FPV technologies concluded that floating PV systems can reduce the evaporation up to $33 \%$ on natural lakes and ponds and $50 \%$ on human-made facilities.

The combined economic value of saving water and production of electricity renders the proposed project very attractive economically and reduces the breakeven time for the project.

\section{Solar Energy Potential}

Lake Nasser is located in one of the richest areas in solar energy in the world as shown in Figure 8 [41], with an average daily solar energy of about $6.72 \mathrm{kWh} / \mathrm{m}^{2}$ Global Horizontal Irradiance (GHI), while the average Direct Normal Irradiance (DNI) reaches $7.92 \mathrm{kWh} /$ day [42]. The yearly average DNI power is between 320 and $340 \mathrm{~W} / \mathrm{m}^{2}$, while the yearly average GHI power is between 280 and $290 \mathrm{~W} / \mathrm{m}^{2}$. The average PV potential in the Aswan region is estimated to be $2455 \mathrm{kWh} / \mathrm{y}$ per square meter [42].

However, the average daily incident solar energy experiences some seasonal variation over the course of the year. The brighter period of the year lasts for 3.9 months, from April 28 to August 25, with an average incident short wave energy of $7.6 \mathrm{kWh}$ /day per square meter, with an average peak of $8.4 \mathrm{kWh} /$ day per square meter. The darker period of the year, from November to January 31, has an average incident short wave energy per square meter of $5.3 \mathrm{kWh} /$ day. The average monthly sun hours are close to 322 hours/month as shown in Figure 9. The average annual amount of sun hours is 3865.0 hours for 2018. The average in July and August exceeds 380 sun hours [43]. With a low-cost PV technology of $21 \%$ efficiency, we expect an average daily solar electric energy of $1.41 \mathrm{kWh} / \mathrm{m}^{2}$.

In inland installations, the reflections from the surrounding hot land surface contribute to the overheating of land PVs and reduce the PV efficiency. The temperature has a negative effect on the PV cell power $[44,45]$. A typical solar cell power versus temperature is shown in Figure 10. The figure shows a PV module peak power versus voltage when its temperature varies between $25^{\circ} \mathrm{C}$ and $65^{\circ} \mathrm{C}$ in steps of 20 
SOLAR RESOURCE MAP

GLOBAL HORIZONTAL IRRADIATION

EGYPT

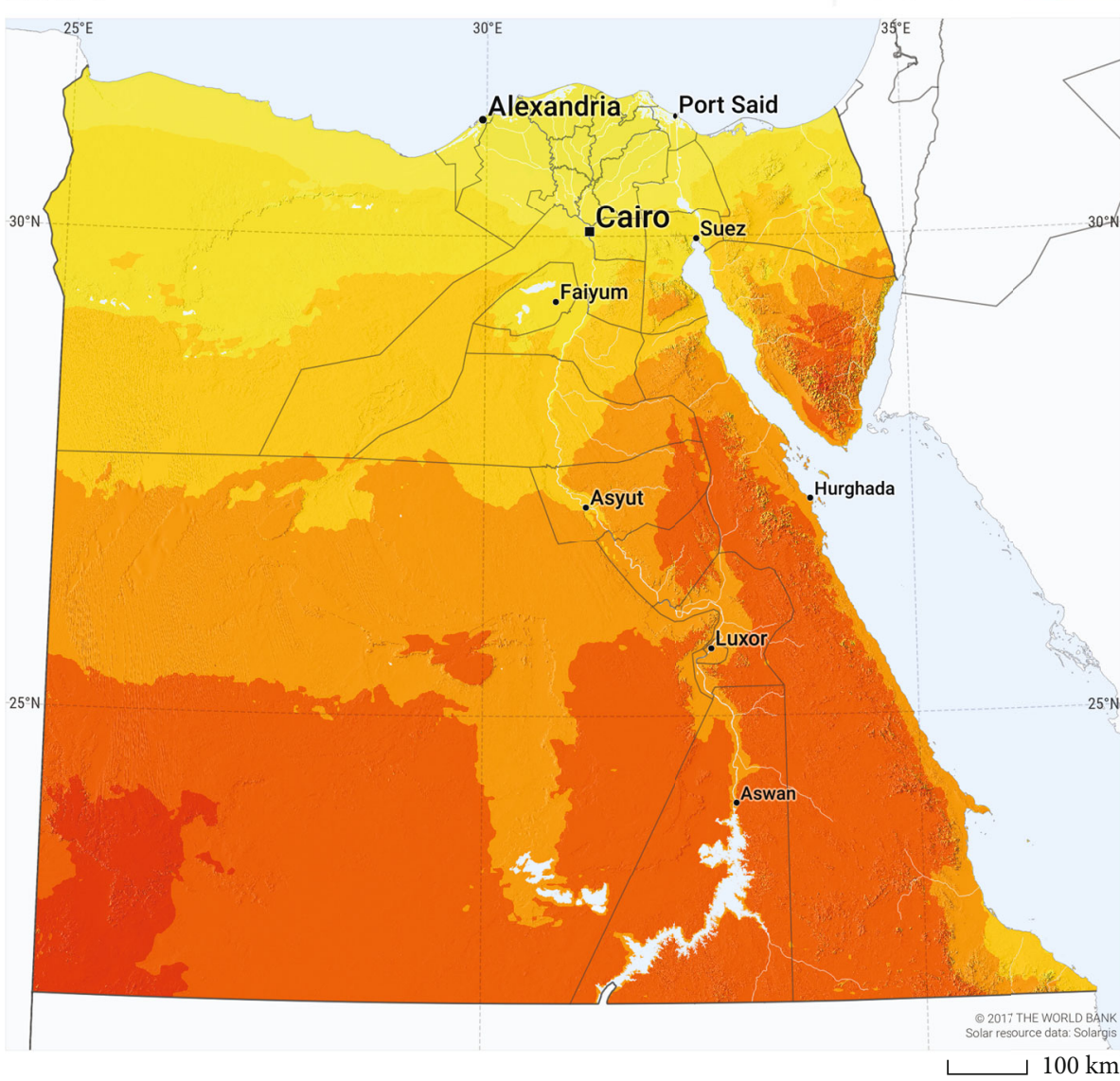

Long term average of GHI, period 1994-2015

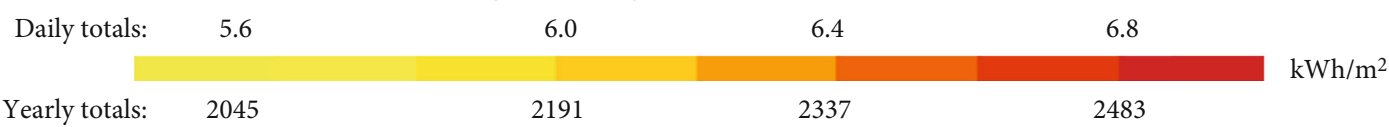

FIGURE 8: Average daily GHI solar irradiation in kWh/day [41].

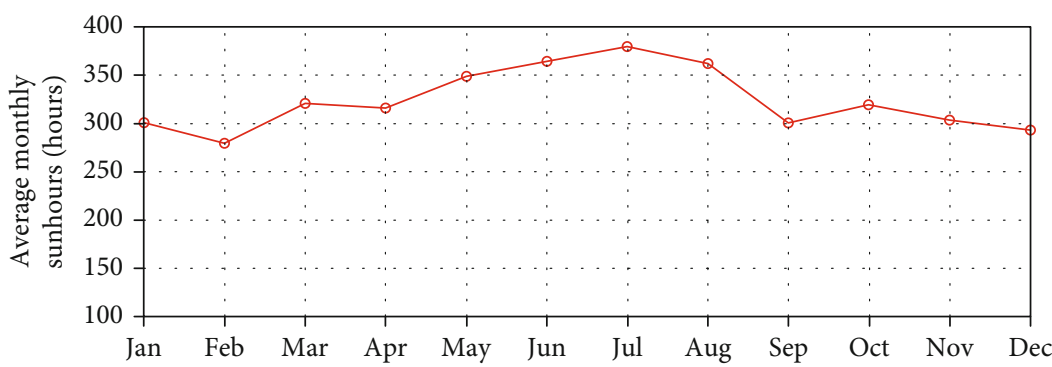

Figure 9: Average monthly sun hours at Aswan city [43].

degrees at a constant $1000 \mathrm{~W} / \mathrm{m}^{2}$ solar irradiance. The figure indicates clearly the negative effect of increased panel temperature on the panel output power.

Several studies verified the higher efficiency of FPV installations, between 10 and $17.5 \%$, over inland installations due to the cooling effect of water bodies. For example, a study of the performance of $100 \mathrm{~kW}$ and $500 \mathrm{~kW}$ floating PV systems on a reservoir in South Korea showed that both systems provided a higher power generation during the whole test period compared to an overland PV system. The study concluded that the floating PV system has a higher production capacity by $7.6 \%$ to $13.5 \%$ than that of the ground-mounted 


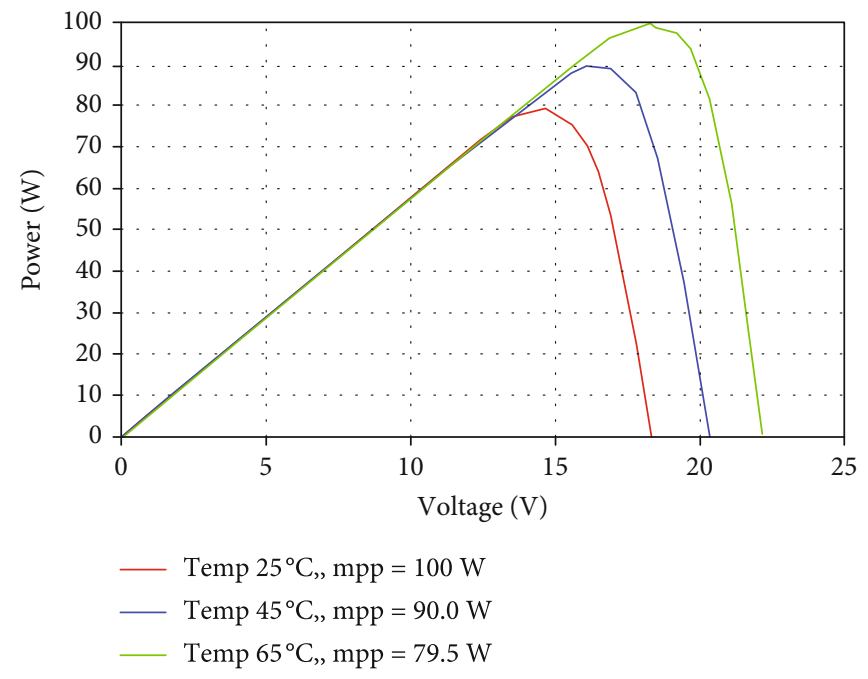

Figure 10: Temperature-dependent PV module power output [44].

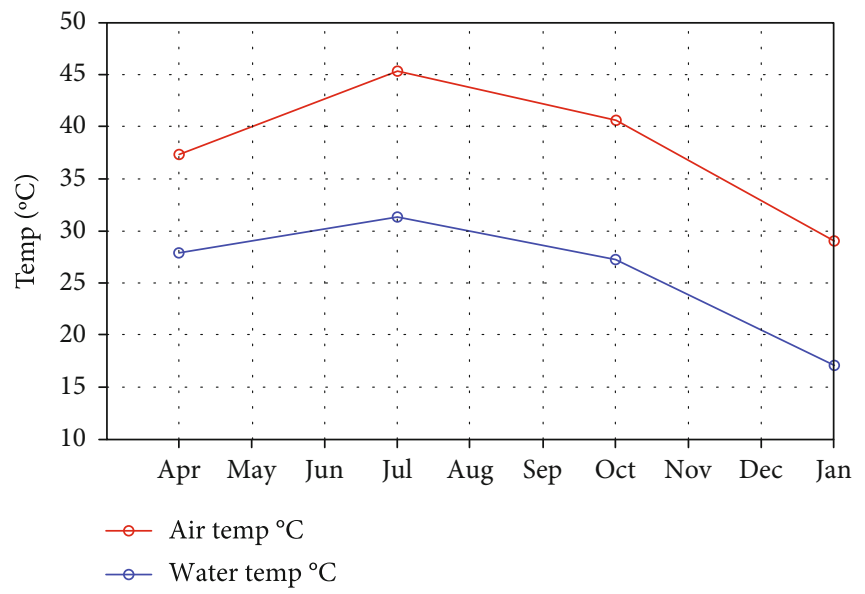

FIGURE 11: Lake Nasser surface temperature compared with air temperature [11].

PV system [46]. A modelling study showed that placing solar arrays on the water will increase their energy output and efficiency levels by $8 \%$ to $10 \%$ [47].

In spite of the hot air temperature, especially in summer, surface water temperature of Lake Nasser depicts mild temperature compared to the air temperature, as shown in Figure 11, and could considerably contribute to boost the efficiency of the FPVs.

Accordingly, based on the cited studies and the mild water temperature of Lake Nasser, we expect between 8 and $13 \%$ improvements in efficiency over inland installation operating under the same air temperature. However, further field studies are needed to obtain accurate figures to support the cost-benefit analysis of the operating companies.

\section{Market and Economic Analysis}

Europe's consumption of electricity between 1990 and 2016 is shown in Figure 12. In 2016, Europe consumed almost $3100 \mathrm{TWh} / \mathrm{y}$, which is about $8.49 \mathrm{Giga} \mathrm{kWh} /$ day [3].
Germany, France, and United Kingdom had the highest electricity generation in 2016 among the EU member states, with each double-digit share. According to Figure 13, the share of solar energy was just $3.5 \%$ of the total electric generation in 2016, while the combustible fuels account for $48.7 \%$.

The Lake Nasser solar energy project is expected to be executed in two or three phases. The first phase is aimed at covering about $1000 \mathrm{~km}^{2}$ of Lake Nasser by PV panels over a period of 10 years. Accordingly, the first phase of the project could supply enough electricity for Europe to replace at least $30 \%$ of combustible fuel in Europe, with the potential for entirely replacing combustible fuel by 2050 , in the subsequent phases.

The study conducted by Fraunhofer ISE [5] forecasted the cost of wind, PV, and concentrated solar power (CSP) up to 2050 and concluded that by 2050 the electricity production costs for the generation potential of $2000 \mathrm{TWh} / \mathrm{y}$ will be $€ 50 / \mathrm{MWh}$ for wind power, below $48 € / \mathrm{MWh}$ for $\mathrm{PV}$, and under $€ 56 / \mathrm{MWh}$ for CSP. According to this report, PV would be the lowest installation cost for massive projects and the lowest production cost. The report emphasised the 


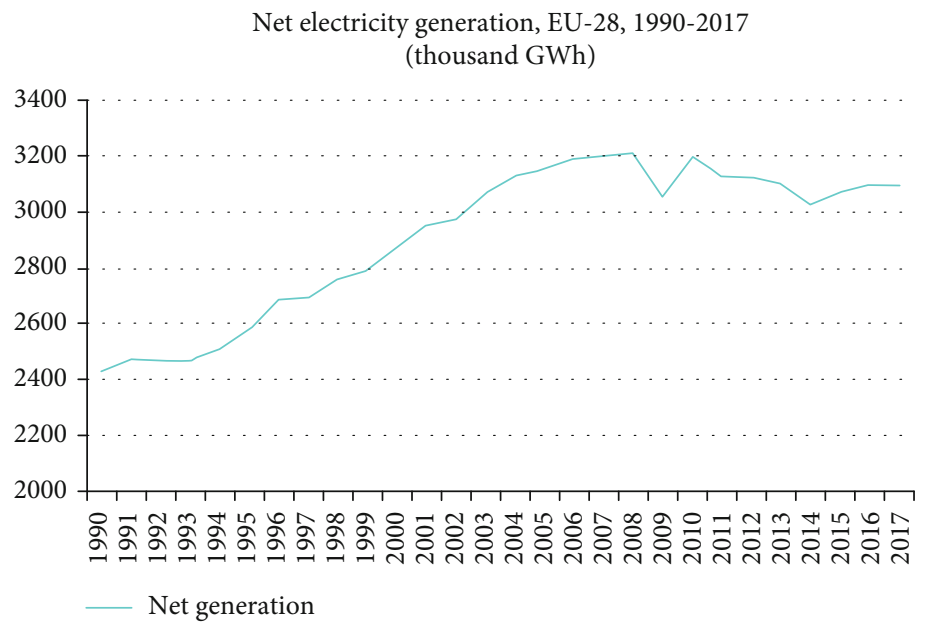

Figure 12: Electricity generation in Europe from 1990 to 2017 [3].

importance of integrating the solar energy production in North Africa with the Europe power grid. Various economic studies also concluded that the PV solar electricity will be the lowest among all sources of electricity [48].

Another study by Fraunhofer ISE [49] indicated that the cost of electricity for industrial applications is between 7 and $18 € / \mathrm{MWh}$ among the European countries with an average of about $12 € / M W h$. On the other hand, the cost of household consumption is from 10 to $31 / \mathrm{MWh}$ and is expected to reach between 55 and $65 € / M W h$ by 2040 . The market size of the electricity sector in Europe is estimated to be 372 billion euros.

As such, the MENA solar electricity should reach the European market at 4-5 euro cents $/ \mathrm{kWh}$, including the transmission cost [50].

With the increasing $\mathrm{CO}_{2}$ taxes in Europe, the Egyptian solar electricity could easily penetrate the European electricity market, with the potential to overtake and replace the combustible fuel electricity market by 2050 . The Lake Nasser solar energy project has the potential of meeting the European future needs of electricity, as the project continues to expand horizontally by increasing the coverage area and vertically by using more efficient PV technologies.

The first phase of the Lake Nasser project is aimed at covering about $20 \%$ of the Lake Nasser, which is almost $1000 \mathrm{~km}^{2}$. The target surface area can be divided into approximately $25 \mathrm{~km}^{2}$ lots. Egypt may then seek multi-international investors and contractors to build and operate this Tera project with revenue sharing for the lifetime of the project (20-25 years) or auction-based bidding, with a condition to remove the PV panels after the expiration of the license term.

First, we assume that about $20 \%$ of the assigned lot surface will be used for service. The actual covered surface area will then be 20 square $\mathrm{km}$. We further assume the PV panels are horizontally laid and occupy about 0.8 of the floating platform. The remaining $20 \%$ of the platform surface is used for cables, power electronics, instrumentation, and walkways. The total PV surface area $=0.8 \times 20 \times 10^{6}=16.0$ million $\mathrm{m}^{2}$.

In this preliminary analysis, we assume that we use low-cost PV technology of $21 \%$ efficiency and the GHI

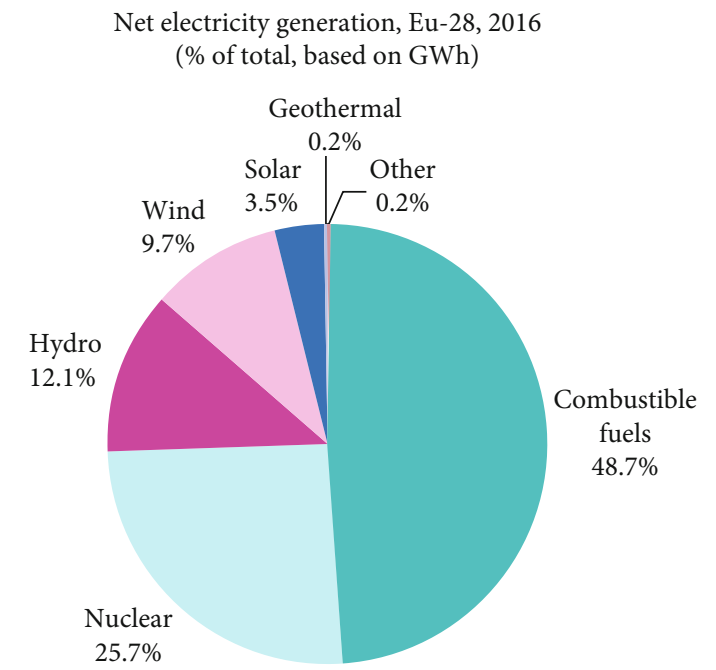

FIGURE 13: Sources of electricity generation in Europe [3].

of $6.72 \mathrm{kWh} / \mathrm{m}^{2}$ at Aswan region [42]. The expected average daily solar electric energy will then be $1.41 \mathrm{kWh} / \mathrm{m}^{2}$ per day.

The electricity production $=1.41 \times 16.0 \times 10^{6} \times 365=$ $8.23 \times 10^{+9} \mathrm{kWh} / \mathrm{y}$.

The cost of a floating platform, if manufactured in Egypt, is estimated to be less than $1 \$ / \mathrm{m}^{2}$.

The last two (2019-2020) years have witnessed an accelerated decrease in the cost of PV installations. A review of the lowest solar power prices in the world, as of January 28 , 2021, showed that the auction bidders' price of kWh of utility scale PV installation around the word came down in the range from 1.35 to $1.97 \$ c e n t / k W h$ [51]. This sharp drop in solar panels cost over the last few years came due to many advances in PV cell technology including the following:

(i) Crystalline silicon (c-Si) PV cells are the most popular technology in PV installations, mainly because of its fast decrease in its cost $(\$ / \mathrm{Wp})$ and its proven reliability. As of 2020, monocrystalline silicon (c$\mathrm{Si}$ ) module pricing is around $\$ 0.20 / \mathrm{W}$ and multi-c- 


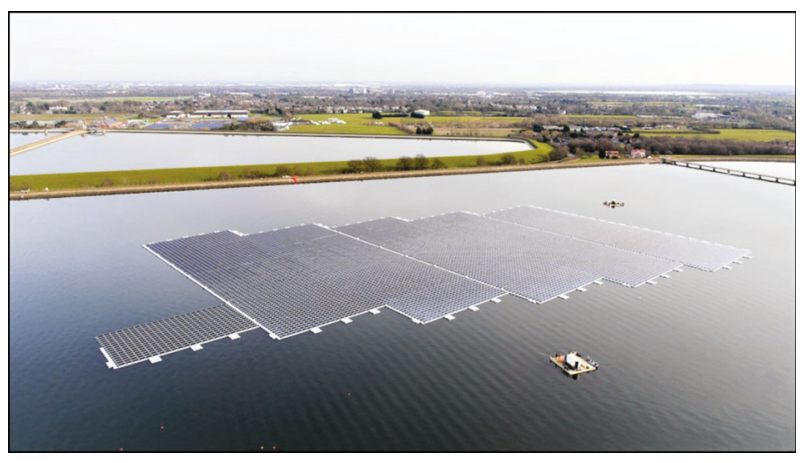

FIGURE 14: 6.3 MW floating solar farm in London's Queen Elizabeth II reservoir [62].

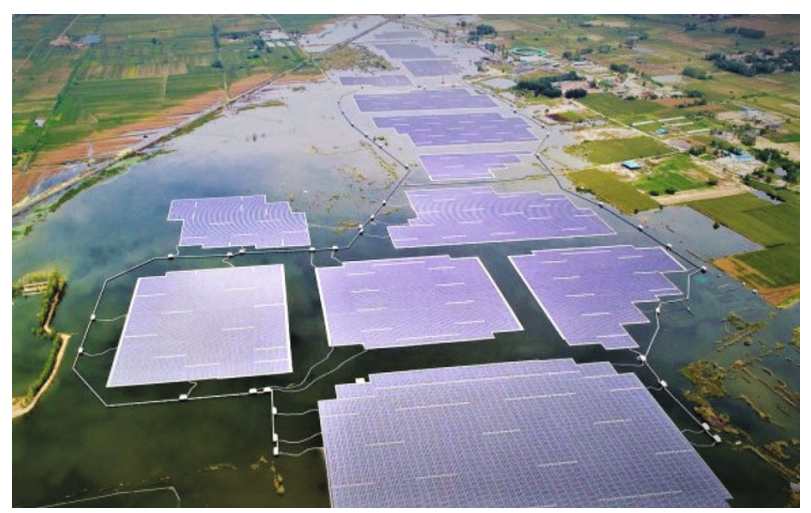

FIGURE 15: Massive floating PV farm in China [63].

Si module pricing is around $\$ 0.17 / \mathrm{W}$. However, it has limited efficiency and it is heavier than the thin film technology. Current research efforts focus on ultrathin crystalline silicon absorber layers, improving production techniques and optimizing growth processes, which could lead to further decrease in its production cost and module weight [52]

(ii) Concentrator photovoltaic (CPV) uses lenses or curved mirrors to focus sunlight onto small, highly efficient, multijunction (MJ) solar cells. Experimental CPV modules demonstrated up to $46.0 \%$ efficiency. CPV could be promising technology for Lake Nasser installations because it works better under normal irradiation [53]

(iii) Cadmium telluride (CdTe) panels are the most popular type of thin-film solar technology used in installations today. The main energy-producing layer is made from cadmium telluride. A substantial efficiency gain in the past several years, achieving lifetime efficiencies of $22-28 \%$, is by implementing $\mathrm{CdSeTe}$ in the absorber layer [54]. Moreover, the proposed CdSeTe technology improves lifetime and other important performance parameters of the solar cell [55]

(iv) Passivated Emitter and Rear Cell (PERC) technology has significantly increased the efficiency of mono- crystalline silicon (c-Si) and multi-c-Si modules and lowered their manufacturing cost. PERC technology increases the cell's ability to catch longer wavelengths. The longer wavelengths are especially present during mornings and evenings or during cloudy days. Current, 2020, PERC PV panels have efficiency between 19 and 22\% [56]

(v) Other new high-efficiency technologies, but more costly, include IBC (interdigitated back contact cells) and HJT (heterojunction cells) [57]

These technological trends will continue to contribute to further reduction in the PV installation cost and/or increase the electricity production per $\mathrm{m}^{2}$. Technology trends are also risk factors and must be examined carefully by the investors, and they need to weigh initial installation cost against longterm benefit from high-cost high-efficiency panels.

(i) Disruptive technologies: during such a long-term project, Egypt needs to assess the risk and opportunities created by disruptive technology. For example, photocatalytic water splitting techniques to generate hydrogen have attracted great attention in the last a few years due to its potential for conversion and storage of solar energy [58-60]. Hydrogen has lucrative market $(4-5 \$ / \mathrm{kg}, 2020)$ for high-end cars, ammonia production, hydrogen cells, solar energy storage, petroleum refinery, in various industrial applications, and finally in recycling of $\mathrm{CO}_{2}$ to produce synthetic methane, methanol, and many hydrocarbon products [61]. As such, when this technology becomes mature for deployment over a large water area, it could be more profitable than FPV

\section{Floating Platforms}

The last few years have witnessed a significant growth of the FPV worldwide. The first large-scale float PV project in Europe was deployed in 2017, on the Queen Elizabeth II reservoir in the UK (Figure 14). The FPV development consists of 23,046 PV panels, each installed on a float and grouped together to form a floating platform. The solar panels were then towed to the middle of the reservoir and fixed in place using 177 anchors [62].

China completed in 2018 the world's largest floating PV farm; see Figure 15. The project spread across 13 separate islets on an area of 140 hectares $\left(1,400,000 \mathrm{~m}^{2}\right)$, with grid connection, testing, and commissioning carried out in March 2019 [63].

The Taiwanese government has embarked upon a 181 MW floating solar project at the Changhua Coastal Industrial Park. The project is the start of an ambition plan to install $20 \mathrm{GW}$ of solar power by 2025 [64].

A floating solar PV system usually consists of five subsystems [65], as shown in Figure 16, the PV subsystem, the floating platform, the mooring subsystem, the underwater cables which transfer the generated power to the land, and the electric power and the control subsystem. 


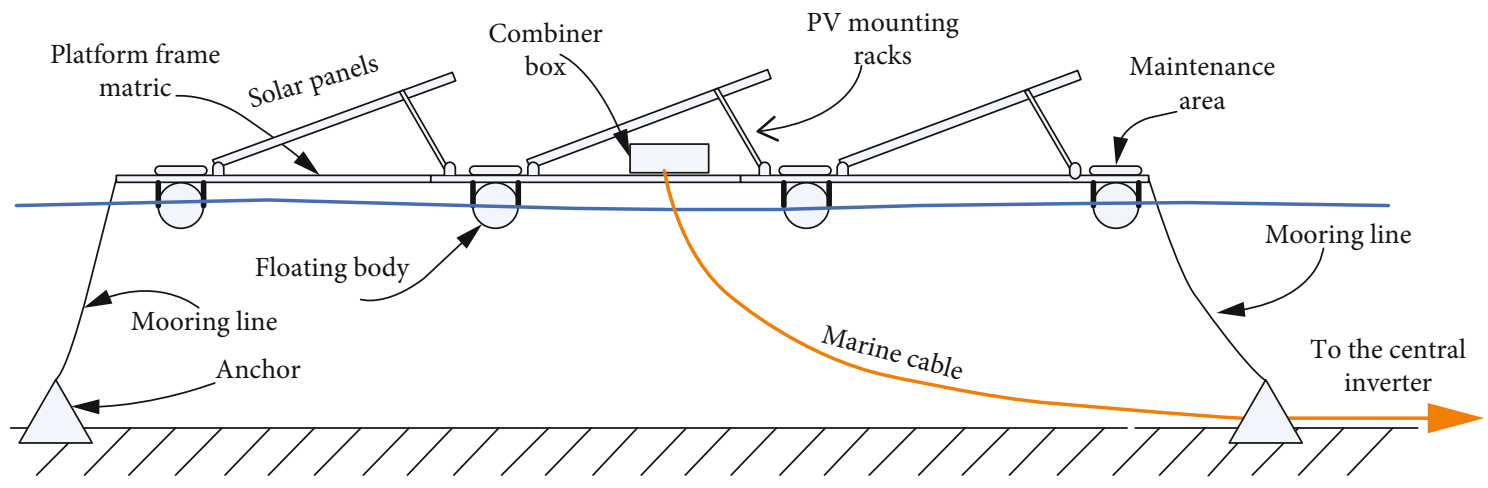

Figure 16: Components of a floating PV system.

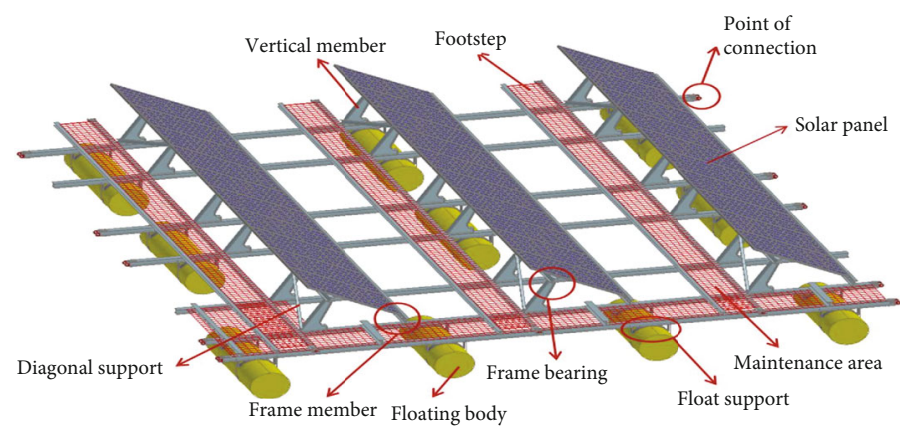

FIGURE 17: Frame array design of FPV floating platform [66].

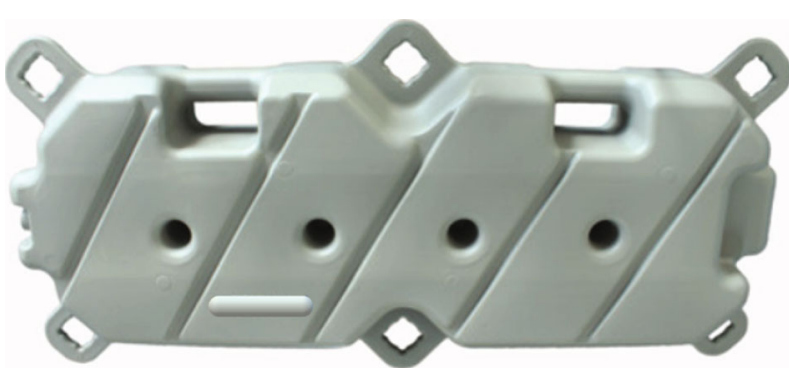

(a)

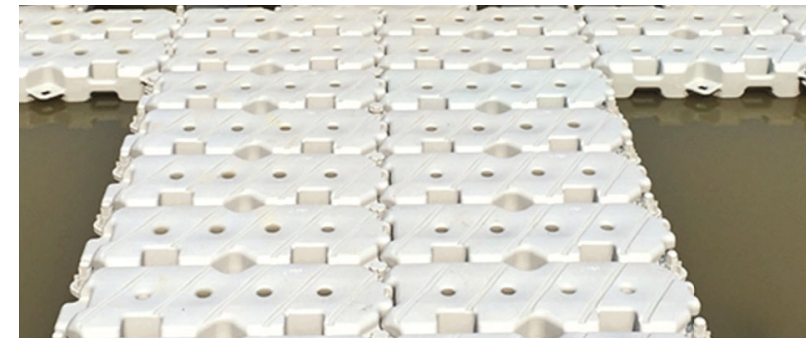

(b)

Figure 18: (a) Float module. (b) Connected modules forming pontoon.

The floating subsystem includes the floating structure, pontoons, floaters, and mounting racks of the PV panels. The mooring subsystem stabilizes the position of the floating platform and automatically adjusts itself for the variation in the water level. A mooring system is made up of a mooring line and an anchor. The mooring line connects an anchor on the lake floor to the floating structure.

There are two main classes of design of the floating platforms: frame arrays and independent floatings [66]. The frame array is common in the over $1 \mathrm{MW}$ installations. The system consists of rows of floats of cylindrical or rectangular section (see Figure 17), on which the structure of PV panels' frames is arranged as repeated arrays. The system is easy to maintain and provides better ventilation and PV generation by water effect. Independent floatings are modular units, usually made of HDPE, which can be fixed together by connection points to form surface pontoons (Figure 18), on which the PV panels are mounted, using fiber-reinforced plastics (FRP) [67].

The size of the floats is an important parameter in the design of the platform. The buoyant force, which is equal to the weight of displaced fluid, must be able to balance the gross weight of the platform under all operating and environmental conditions.

In the following example, we present a simplified calculation of the buoyant force for a platform module, which supports 8 standard 96-cell PV panels. The PV panels have frame dimensions of approximately $160 \mathrm{~cm} \times 110 \mathrm{~cm}$.

Ex.1: the overall floating platform surface is 4.4 meters $\times 3.8$ meters $=16.72 \mathrm{~m}^{2}$, supported by 3 high-density polyethylene (HDPE) closed-end pipes of diameter $D=63 \mathrm{~cm}$, each of length 4.4 meters, as shown in Figure 17. The panels are mounted on galvanized steel racks. The weight budget is given in Table 2. 
TABLE 2: Weight budget of the example module.

\begin{tabular}{lcccccc}
\hline & Panels & $\begin{array}{c}\text { Cables and } \\
\text { electronics }\end{array}$ & Frames & Pipes & Crew & Total \\
\hline Each & 18.9 & & & $48.55 / \mathrm{m}$ & & \\
Total kg. & 151.2 & 30 & 117 & 640.9 & 250 & $1189 \mathrm{~kg}$ \\
\hline
\end{tabular}

The parameters used for the following calculations are shown in Figure 19(b). The submerged pipe cross-sectional area, $A_{\mathrm{s}}$, is given by

$$
A_{\mathrm{s}}=\theta *\left(\frac{D}{2}\right)^{2}-L_{1} * L_{2}
$$

The buoyant force is given by

$$
F_{\mathrm{B}}=g * \rho_{\mathrm{w}} * L_{\mathrm{p}} * A_{\mathrm{s}},
$$

where $L_{\mathrm{p}}$ is the total HDPE pipe length and $\rho_{\mathrm{w}}$ is the density of the water.

Figure 20 shows the plot of the gross weight of the platform (to be carried by the buoyant force) and the submerged depth $h$. The graph indicates that for the gross weight in Table 2 the submerged depth is about $21 \mathrm{~cm}$.

The wide span of possible water level variation of Lake Nasser (about 6 meters every year) is a challenging problem and requires special considerations in the design of the anchoring and mooring system. Two common anchoring methods have been used for FPVs; anchoring at the banks is the most cost-effective anchoring system, while anchoring at the bottom is the most widely installed. Both options should be carefully studied.

To overcome the problem of varying water levels, anchoring isles can be placed at the corners of the floating platform, where anchoring wenches with automatic tension adjustment can be installed. Alternatively, a technique using hanging loads, called auxiliary mooring structure, is shown in Figure 21 . The auxiliary mooring structure operates simply by gravity of the auxiliary weights.

A low-cost structure, shown in Figure 22, is being investigated at Zewail City of Science and Technology, Egypt, which utilizes UPVC pipes for the floating frame and marine-grade foam for the pontoons. The supporting structures of PVs are made of galvanized steel sections. The modules are made to fit inside standard shipping containers to facilitate transportations. The connection of the units is made with special rubber strips to mitigate the effect of $6 \mathrm{D}$ displacements between the units.

Considering PV tilting options, the flat horizontal panels could be the best option due to several reasons; being omnidirectional simplifies design and installation, eliminates shadow problems, and reduces maintenance cost. However, it is not theoretically efficient, compared with tilted solutions. Nevertheless, the loss of efficiency is compensated by the increase of efficiency due to the cooling effect of the water surface. The direction of the wind in Lake Nasser is mainly north (see Figure 6), which would make a flat design more favourable to avoid wind forces on the tilted structures.

The second tilting option is using a single tilt angle. However, it needs to be orientation-stabilized on the water surface, which increases the platform construction and installation cost and could create shadow problems and leaves limited options for modular design. On the other hand, it increases energy production by $5 \%$ over the flat platform. The fixed tilt angle at latitude of 22 degrees is about 18 degrees (facing south) [67].

For the two-angle option, Table 3 , in addition to the increase in the cost of the platform modules, it substantially increases the maintenance and operational costs.

For four angles, the tilt angles for spring and fall would be about 20 degrees [68]. Fully steerable 2D PVs need lifetime cost-benefit analysis, considering the potential for increased output by $25 \%$ over the flat surface. The use of PV tilting options requires new innovative solutions to be a truly viable option in such massive projects.

\section{Solar Energy Storage Solutions}

Solar energy storage enables the use of solar energy 24 hours. With the fast introduction of solar energy, the energy storage market will see rapid expansion in the next few years: the global storage market is forecasted to reach at least $\$ 250$ billion by 2040 [69].

Expanding the use of solar energy requires, on the one hand, an hourly based tariff to encourage customers to save solar energy during the day and, on the second hand, a distributed approach for solar energy storage. The geographically distributed solution could be at three vertical levels of energy storage:

(1) Residential battery storage

(2) Industry/enterprise level energy storage

(3) Utility or state energy storage

The residential energy storage batteries can be made to charge when tariff is the lowest and turned on during the highest tariff rates. Such small-scale electric storage solutions will have a crucial role in expanding onsite consumption. There are several emerging battery technologies which promise low cost and higher capacities [70].

For industry and enterprises with up to $200 \mathrm{MW}$, cryogenic energy storage [71] could be a very promising solution. Cryogenic technology converts air to liquid by cooling down air to $-196^{\circ} \mathrm{C}\left(-320^{\circ} \mathrm{F}\right)$. The air then can be efficiently stored in insulated rooms. When air is brought to ambient temperatures, it regasifies and its volume expands to 700-fold, which is then used to drive a turbine and generate electricity without combustion. These systems can be built from $10 \mathrm{MW}$ to more than $200 \mathrm{MW}$ power output, with a storage capacity more than $2000 \mathrm{MWh}$. The lifespan of cryogenic energy storage systems is over 30 years with efficiency between 60 and $75 \%$. Large-scale batteries are also available [72] for small and medium enterprises. 


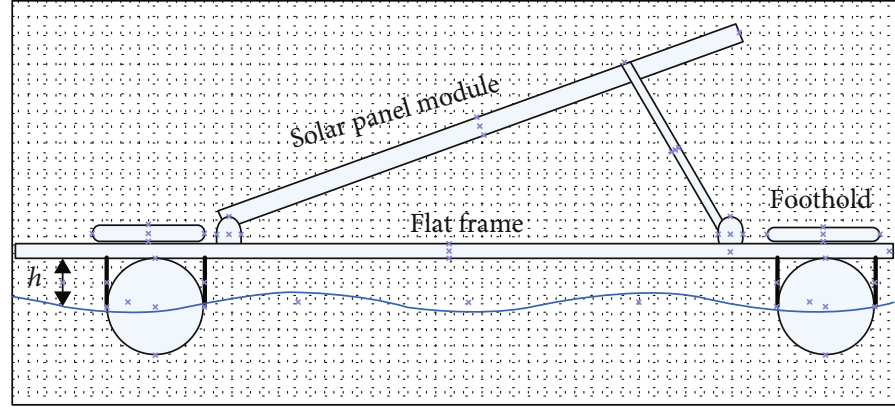

(a)

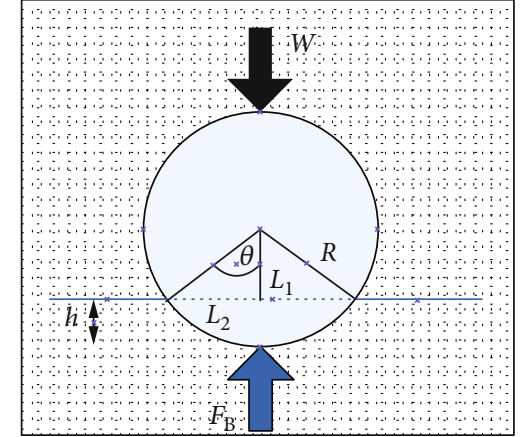

(b)

FIgURE 19: (a) Illustration of mounting racks carried by pipe pontoons. (b) Parameters used to calculate the bounce force in Ex.1.

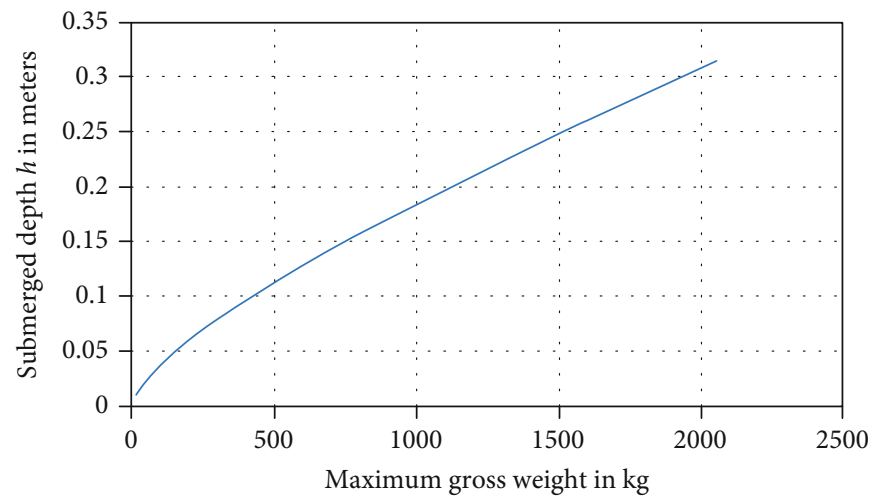

FIGURE 20: Plot of the submerged depth against gross weight of the FPV module in Ex.1.

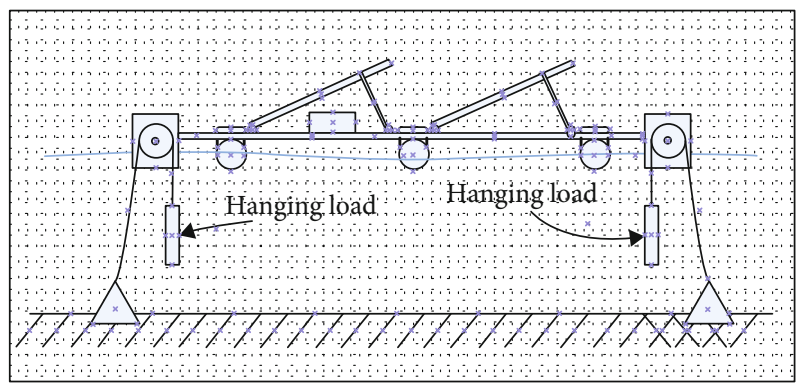

Figure 21: Auxiliary mooring structure for variable water levels $[66]$.

For utility and large-scale energy storage, two technologies are available; the first one is hydraulic pumping, where pumps are used to move water to higher level tanks, converting the electric energy to gravitational energy during the day time and then using it to drive turbine generators at night. Because of the simplicity and low cost of this approach, pumped hydro plants account for almost $96 \%$ of current large-scale installations $[70,73]$. In addition, pumped hydro plants are a mature technology, capable of storing huge amounts of energy, and have relatively high efficiency (70$80 \%$ ) and expected lifespan of 40-60 years. Pumped hydro systems could be a viable energy storage solution bringing water from Lake Nasser to nearby higher level areas, which exist on the east side of Lake Nasser. Nevertheless, such hydraulic plants are expected to support only a few gigawatts of power, which is far below the scale of the project. We believe a distributed energy storage solution would be the most economical and practical solution. The second approach for utility scale energy storage is to convert energy into fuel, for example, using electricity to generate $\mathrm{H}_{2}$ from water by electrolysis $[73,74]$. Hydrogen may then be stored or transported and used as a fuel. The generated $\mathrm{H}_{2}$ could be used in a process known as methanation [74], where the generated $\mathrm{H}_{2}$ is combined with captured $\mathrm{CO}_{2}$ to generate synthetic methane, which could then be stored and transported. The process has a positive impact on the environment by utilizing captured $\mathrm{CO}_{2}$ from $\mathrm{CO}_{2}$-emitting industries.

\section{Impact on Environment and Fishery Sector}

The current production of fish from Lake Nasser is about 26,000 ton $/ y$ that is less than 5.2 ton per $/ \mathrm{km}^{2}$ or $5.2 \mathrm{~kg} / 1000 \mathrm{~m}^{2}$. In fact, it is reported that during the recent years, with the growing number of fishing boats and poor compliance with the technical measures, the yield from the fishery in Lake Nasser has exhibited a declining trend since 1981, indicating unsustainable rates of exploitation [75].

On the other hand, according to [76], cage fish farming along a coastal line could yield $20 \mathrm{~kg}$ per $\mathrm{m}^{3}$ of water with trained operators and properly regulated and managed cage farming [77].

The large number of small Khors along the coastline of Lake Nasser can be converted to fish enclosures [78] by 


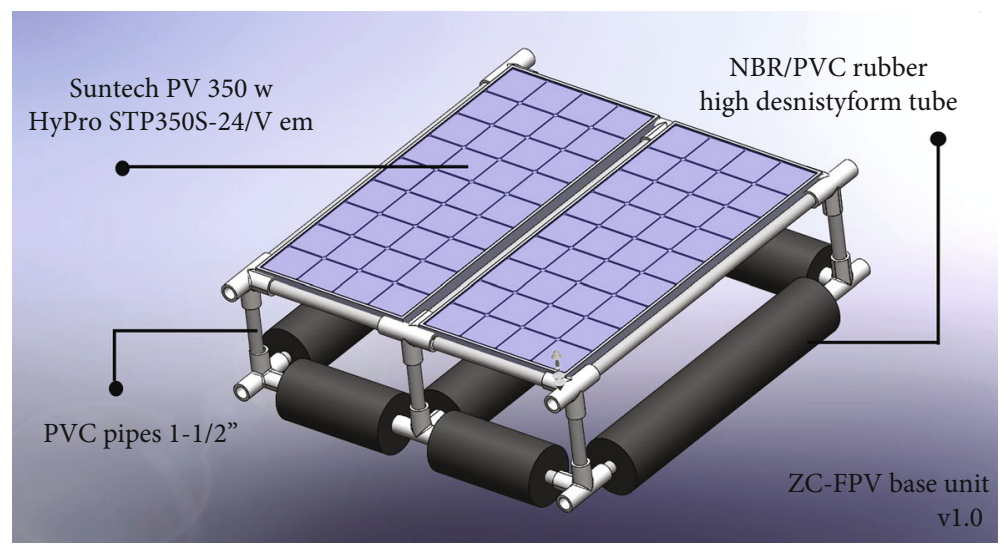

FIgURe 22: A half unit of a proposed low-cost float PV module.

TABLE 3: The two-tilt angle option.

\begin{tabular}{lcc}
\hline & Northern hemisphere & Tilt angle \\
\hline Adjust to summer angle on & March 30 & No tilting \\
Adjust to winter angle on & September 10 & 45 degrees \\
\hline
\end{tabular}

closing their entrance by a large net. Enclosures increase production per unit of area and make it possible to adopt intensive culture practices and protection from predators. As such, the impact of the project on Lake Nasser fishery can be mitigated by modernizing the current unsustainable fishing practices. Moreover, the available low-cost electricity from the project will enable the introduction of state-of-the-art value chain and introduction of lucrative fish industries.

On the other hand, several positive environmental impacts of FPVs were consistently reported in the literature. For example, it is reported in [79] that the shade provided by the FPVs reduces the presence of algae blooms in bodies of freshwater. Algae blooms can be dangerous for human health if they occur in a source of drinking water and can also lead to the death of plants and animals living in the body of water.

An NREL-sponsored study [80] in the USA reported that floating PVs can help mitigate algae growth in water bodies. Another benefit of shading water surfaces is the reduction of the incidence of solar radiation in water and therefore its temperature. The reduction in water temperature increases phytoplankton growth rates, which is an important player in the fish food chain [81].

During the course of execution and operation of such a massive project, several precautions must be taken into consideration to avoid adverse impacts on the environment. In a study sponsored by the Asian Development Bank (ADB) [82], it discusses several potential environmental impacts of FPV projects and proposes a number of mitigation measures. The construction phase usually involves site preparation (e.g., grading and levelling), transportation, installation, and commissioning of infrastructure (including the floats, PV panels, inverters, transformers, access road, transmission lines, and land control centres). These activities are likely to generate air emissions and impacts on land and aquatic habitats. Mitigating measures include land and water traffic management, and regulatory measures during the construction phase should be enforced regarding using appropriate machinery, trucks, cars, and waste and oil waste disposal measures.

During operation, it is also recommended to place zoning, water and landmarks, and separation of the regular waterway traffic from the maintenance traffic. Contractors will be responsible to report and clean construction wastes, debris, and parts that could accidentally fall in the land or in water. In addition, the use of chemicals on the floating PVs should be prohibited.

Finally, the license contract should stipulate removal the PV panels at the end of the project and dispose them in accordance with the recommendations of the International Renewable Energy Agency (IRENA) and the International Energy Agency Photovoltaic Power Systems (IEA-PVPS) [83] or according to the international regulations at the time of the decommissioning of the project.

Nevertheless, the project is expected to generate a range of positive impacts on the local community including local training and employment opportunities as well as substantial growth opportunities for local business and industry.

\section{Conclusions}

The paper presented a study of the energy production and water saving of a massive deployment of floating PVs over Lake Nasser in south Egypt. The area is very rich in solar energy. It also enjoys mild wind, low surface waves, and almost year-round sunshine. If only $20 \%$ of the lake is covered, about $1000 \mathrm{~km}^{2}$, it will produce low-cost green electricity that is enough for almost $16 \%$ of European need, with the potential to entirely replace coal- and fossil-based electricity in Europe during the subsequent phases of the project. The project will also help to reduce water loss by evaporation from Lake Nasser, which represents almost $20-25 \%$ of the Egyptian yearly consumption of water. The availability of low-cost electrical energy could make Lake Nasser's neighbourhood a world hub for electric energy intensive industries.

\section{Data Availability}

Links to the sources of data are listed in the reference section. Generated data and calculations will be made available after publication, upon request. 


\section{Conflicts of Interest}

The authors declare that there is no conflict of interest regarding the publication of this paper.

\section{Acknowledgments}

The authors would like to thank Zewail City of Science and Technology for its support of this study.

\section{References}

[1] J. Vogler, "The European contribution to global environmental governance," International Affairs, vol. 81, no. 4, pp. 835-850, 2005.

[2] "Europe Renewable energy directive," https://ec.europa.eu/ energy/en/topics/renewable-energy/renewable-energydirective/overview.

[3] Eurostat, "Electricity production, consumption and market overview - Statistics Explained," December 2019, https://ec .europa.eu/eurostat/statistics-explained/index.php/Electricity_ production,_consumption_and_market_overview.

[4] T. Buck, "Decline in new German wind farms sparks concern," Financial Times, 2019, https://www.ft.com/content/b0f94478c998-11e9-alf4-3669401ba76f.

[5] W. Platzer, I. Boie, M. Ragwitz et al., Supergrid studyapproach for the integration of renewable energy in Europe and North Africa, Technical report, Fraunhofer Institute for Solar Energy Systems ISE, 2016.

[6] https://en.wikipedia.org/wiki/Benban_Solar_Park.

[7] F. Haugwitz, "Floating solar PV gains global momentum," $P V$ Magazine, September, vol. 22, 2020https://www.pv-magazine .com/2020/09/22/floating-solar-pv-gains-global-momentum/.

[8] World Bank Group, ESMAP and SERIS, Where Sun Meets Water: Floating Solar Market Report, World Bank, Washington, DC, 2019.

[9] R. Cazzaniga and M. Rosa-Clot, "The booming of floating PV," Solar Energy, vol. 6, 2020.

[10] Aswan Dam Completed, National Geographic Society November 2020, https://www.nationalgeographic.org/thisday/jul21/ aswan-dam-completed/.

[11] L. Nasser, "World Lake Database ILEC," November 2020, http://wldb.ilec.or.jp/Details/Lake/AFR-19.

[12] L. Nasser, "Google Maps,” November 2020, https://www .google.com/maps/place/Lake+Nasser/@22.9671129,31 $.1243976,8 \mathrm{z} / \mathrm{data}=! 3 \mathrm{~m} 1$ ! $4 \mathrm{~b} 1 ! 4 \mathrm{~m} 5 ! 3 \mathrm{~m} 4$ ! $1 \mathrm{~s} 0 \times 1430 \mathrm{e} 4 \mathrm{a}$ 77d1f7c4f:0xb0cafa0627ce54f6!8m2!3d22.7395235!4d32 .1973081 .

[13] R. M. A. Hassan, N. T. H. Hekal, and N. M. S. Mansor, "Evaporation reduction from Lake Naser using new environmentally safe techniques," in Eleventh International Water Technology Conference, IWTC11 2007 Sharm El-Sheikh, Egypt, 2007.

[14] M. A. El-Shirbeny and K. A. Abutaleb, "Monitoring of waterlevel fluctuation of Lake Nasser using altimetry satellite data," Earth Systems and Environment, vol. 2, no. 2, pp. 367-375, 2018.

[15] L. N. Reservoir, "Satellite Radar Altimetry: Global Reservoir and Lake Elevation Database.," December 2020, https://ipad .fas.usda.gov/cropexplorer/global_reservoir/gr_regional_chart .aspx? regionid=metu\&reservoir_name=Nasser.
[16] E. Muala, Y. A. Mohamed, Z. Duan, and P. van der Zaag, "Estimation of reservoir discharges from Lake Nasser and Roseires Reservoir in the Nile Basin using satellite altimetry and imagery data," Remote Sensing, vol. 6, no. 8, pp. 7522-7545, 2014.

[17] H. M. Ebaid and M. Aziz, "Integrating radar altimeters and optical imagery data for estimating water volume variations in lakes and reservoirs (case study: Lake Nasser)," Journal of Geographic Information System, vol. 9, no. 6, pp. 648-662, 2017.

[18] M. M. Mostafa and H. K. Soussa, "Monitoring of Lake Nasser using remote sensing and GIS techniques," ISPRS Mid-term Symposium Proceeding, 2006, May 2006Netherland, 2006.

[19] "Climate in Aswan, Egypt," December 2020, https://www .worlddata.info/africa/egypt/climate-aswan.php.

[20] M. I. El-Mekawy, Z. Salah, and M. M. A. Wahab, "Climatology of Lake Nasser in Egypt," Middle East Journal of Applied Sciences, vol. 8, no. 3, pp. 719-726, 2018.

[21] "Wind direction, Aswan - Egypt," December 2020, https:// www.weatheronline.co.uk/weather/maps/city?WMO= $62414 \& \mathrm{CONT}=$ afri $\& \mathrm{LAND}=\mathrm{EG} \& \mathrm{ART}=\mathrm{WDR} \& \mathrm{LEVEL}=$ $162 \& \mathrm{MOD}=\mathrm{tab}$.

[22] "Average weather in Aswan, Egypt, year round - weather spark,” December 2020, https://weatherspark.com/y/97255/ Average-Weather-in-Aswan-Egypt-Year-Round.

[23] R. H. Goma, "Seasonal and spatial variation of nutrients," in Sustainable fish production in Lake Nasser: ecological basis and management policy, ICLARM Conf. Proc, J. F. Craig, Ed., pp. 33-38, International Center for Living Aquatic Resources Management (ICLARM), Penang, Malaysia, 2000.

[24] G. M. El-Shabrawy, "Lake Nasser-Nubia," in The Nile. Monographiae Biologicae, H. J. Dumont, Ed., vol. 89, Springer, Dordrecht, 2009.

[25] Water politics - sharing the Nile, The Economist, Middle East and Africa, 2016, December 2019, http://www.economist .com/middle-east-and-africa/2016/01/16/sharing-the-nile.

[26] Water scarcity in Egypt, Ministry of Water Resources and Irrigation, Egypt, 2014, http://www.mfa.gov.eg/ SiteCollectionDocuments/Egypt\%20Water\%20Resources\% 20Paper_2014.pdf.

[27] M. E. D. M. Omar and A. M. A. Moussa, "Water management in Egypt for facing the future challenges," Journal of Advanced Research, vol. 7, no. 3, pp. 403-412, 2016.

[28] "Egypt is building world's largest seawater desalination plant, Egyptian Streets," 2017, December 2019, https:// egyptianstreets.com/2017/11/17/egypt-is-building-worldslargest-seawater-desalination-plant/.

[29] M. A. Mosalam Shaltout and T. El Housry, "Estimating the evaporation over Nasser Lake in the upper Egypt from meteosat observations," Advances in Space Research, vol. 19, no. 3, pp. 515-518, 1997.

[30] M. Elsawwaf, P. Willems, A. Pagano, and J. Berlamont, "Evaporation estimates from Nasser Lake, Egypt, based on three floating station data and Bowen ratio energy budget," Theoretical and Applied Climatology, vol. 100, pp. 439-465, 2009.

[31] I. H. Abou El-Magd and E. M. Ali, "Estimation of the evaporative losses from Lake Nasser, Egypt using optical satellite imagery," International Journal of Digital Earth, vol. 5, no. 2, pp. 133-146, 2012.

[32] M. Hassan, "Evaporation estimation for Lake Nasser based on remote sensing technology," Ain Shams Engineering Journal, vol. 4, pp. 593-604, 2013. 
[33] W. G. M. Bastiaanssen, M. Menenti, R. A. Feddes, and A. A. M. Holtslag, "A remote sensing surface energy balance algorithm for land (SEBAL) 1. Formulation," Journal of Hydrology, vol. 212-213, pp. 198-212, 1998.

[34] A. Ashfaque and W. G. M. Bastiaanssen, "Estimating evaporation from Lake Naivasha, Kenya using remotely sensed Landsat Thematic Mapper (TM) spectral data," Journal of Civil Engineering, The Institution of Engineers, Bangladesh, vol. CE28-2, 2000.

[35] M. M. Abdel Wahab, Y. H. Essa, A. A. Khalil, K. Elfadli, and G. Panegrossi, "Water loss in Egypt based on the Lake Nasser evaporation and agricultural evapotranspiration," Environment Asia, vol. 11, pp. 192-204, 2018.

[36] H. M. I. Ebaid and S. S. Ismail, "Lake Nasser evaporation reduction study," Journal of Advanced Research, vol. 1, no. 4, pp. 315-322, 2010.

[37] B. E. Abulnaga, "Harvesting the skies of Egypt: an option to recover the evaporation losses from the Aswan High Dam Reservoir," in Grand Ethiopian Renaissance Dam Versus Aswan High Dam. The Handbook of Environmental Chemistry, A. Negm and S. Abdel-Fattah, Eds., vol. 79, pp. 385-415, Springer, Cham, 2019.

[38] Y. W. Youssef and A. Khodzinskaya, "A review of evaporation reduction methods from water surfaces," E3S Web of Conferences, vol. 97, article 05044, 2019.

[39] M. R. Santafé, J. B. T. Soler, F. J. S. Romero, P. S. F. Gisbert, J. J. F. Gozálvez, and C. M. F. Gisbert, "Theoretical and experimental analysis of a floating photovoltaic cover for water irrigation reservoirs," Energy, vol. 67, pp. 246-255, 2014.

[40] A. Sahu, N. Yadav, and K. Sudhaka, "Floating photovoltaic power plant: a review," Renewable and Sustainable Energy Reviews, vol. 66, pp. 815-824, 2016.

[41] "Solar resource maps and GIS data for 180+ countries, Solargis," December 2020, https://solargis.com/maps-and-gisdata/download/egypt.

[42] P. Kosmopoulos, S. Kazadzis, and H. El-Askary, Solar Atlas of Egypt, European Horizon 2020 Project\# NO 690133, 2018.

[43] "Average monthly hours of sunshine in Aswan (Aswan Governorate), Egypt," December 2020, https://weatherand-climate.com/average-monthly-hours-Sunshine,Aswan, Egyp.

[44] A. Razak, Y. M. Irwan, W. Z. Leow, M. Irwanto, I. Safwati, and M. Zhafarina, "Investigation of the effect temperature on photovoltaic (PV) panel output performance," International Journal on Advanced Science, Engineering and Information Technology, vol. 6, pp. 682-688, 2016.

[45] S. Dubey, J. N. Sarvaiya, and B. Seshadri, “Temperature dependent photovoltaic (PV) efficiency and its effect on PV production in the world - a review," Energy Procedia, vol. 33, pp. 311321, 2013.

[46] Y. K. A. Choi, "Study on power generation analysis of floating PV system considering environmental impact," International Journal of Software Engineering and Its Applications, vol. 8, pp. 75-84, 2014.

[47] A. McKay, Floatovoltaics: quantifying the benefits of a hydrosolar power fusion, [Pomona Sr. theses], Claremont University, 2013.

[48] P. Ralon, Global renewable energy cost trends, International Renewable Energy Agency IRENA, 2018, http://www.reem .org/wp-content/uploads/2018/04/Pablo-Ralon-IRENA.pdf.
[49] C. Kost, S. Shammugam, V. Jülch, H. T. Nguyen, and T. Schlegl, Levelized cost of electricity renewable energy technologies, Fraunghofer ISE, 2018.

[50] A. Dobbins, F. Fuso Nerini, P. Deane, and S. Pye, "Strengthening the EU response to energy poverty," Nature Energy, vol. 4, no. 1, pp. $2-5,2019$.

[51] “Top 10 lowest solar power prices in the world," Febuary 2021, https://commercialsolarguy.com/2020/05/01/lowest-solarpower-prices-in-the-world/accessed.

[52] D. F. R. Margolis, Q2/Q3 2020 Solar industry update, National Renewable Energy Laboratory (NREL), US, 2020, https://www .nrel.gov/docs/fy21osti/78625.pdf.

[53] M. Steiner, T. Gerstmaier, and A. W. Bett, "10 - Concentrating photovoltaic systems," in The Performance of Photovoltaic (PV) Systems, N. Pearsall, Ed., pp. 297-320, Woodhead Publishing, 2017.

[54] W. K. Metzger, S. Grover, D. Lu et al., "Exceeding 20\% efficiency with in situ group $\mathrm{V}$ doping in polycrystalline CdTe solar cells," Nature Energy, vol. 4, no. 10, pp. 837-845, 2019.

[55] M. Rong Wang, "Enhanced performance of Se-alloyed CdTe solar cells: the role of Se-segregation on the grain boundaries," Journal of Applied Physics, vol. 129, no. 2, article 024501, 2021.

[56] A. Blakers, "Development of the PERC solar cell," IEEE Journal of Photovoltaics, vol. 9, no. 3, pp. 629-635, 2019.

[57] J. Svarc, “Most efficient solar panels 2020," 2020, February 2021, https://www.cleanenergyreviews.info/blog/mostefficient-solar-panels.

[58] C. Y. Toe, Z. Zheng, H. Wu, J. Scott, R. Amal, and Y. H. Ng, "Transformation of cuprous oxide into hollow copper sulfide cubes for photocatalytic hydrogen generation," The Journal of Physical Chemistry C, vol. 122, no. 25, pp. 14072-14081, 2018.

[59] H. Wu, "A pulse electrodeposited amorphous tunnel layer stabilises $\mathrm{Cu} 2 \mathrm{O}$ for efficient photoelectrochemical water splitting under visible-light irradiation," Journal of Materials Chemistry A, vol. 8, no. 11, pp. 5638-5646, 2020.

[60] M. Wang and G. Lu, "Improved light harvesting and efficiency for overall water splitting by embedding $\mathrm{TiO}_{2}$ transition," $R R L$ Solar, Wiley Online Library, 2020.

[61] E. C. Ra, K. Y. Kim, E. H. Kim, H. Lee, K. An, and J. S. Lee, "Recycling carbon dioxide through catalytic hydrogenation: recent key developments and perspectives," ACS Catalysis, vol. 10, no. 19, pp. 11318-11345, 2020.

[62] “Europe's largest floating solar farm, Lightsource BP," December 2020, https:/www.lightsourcebp.com/uk/stories/qe2/.

[63] T. Kenning, Worlds-largest-floating-solar-plant-connected-inchina, PV-Tech, 2020, January 2020, https://www.pv-tech .org/news/worlds-largest-floating-solar-plant-connected-inchina.

[64] https://www.floatingsolarmounting.com/news/181 mwfloating-pv-plant-in-taiwan-china-obtained-financing.html..

[65] N. D. A. Thi, "The global evolution of floating solar PV," 2017, https://www.researchgate.net/publication/321461989_The_ global_evolution_of_floating_solar_PV.

[66] LG CNS, "Floating PV Design and Quality Challenges," 2017, https://www.ibesalliance.org/fileadmin/content/download/ presentation/2017/JF4S_Intersolar_Middle_East/2._Veyis_ Neo_TOPRAK.pdf.

[67] S. H. Kim, S. J. Yoon, and W. C. Choi, "Design and construction of $1 \mathrm{MW}$ class floating PV generation structural system 
using FRP members," Energies, vol. 10, no. 8, article 1142, 2017.

[68] "Solar Electricity Handbook, 2019 Edition, Solar Panel Angle Calculator," December 2020, http://www.solar electricityhandbook.com/solar-angle-calculator.html.

[69] https://www.solarpowereurope.org/priorities/solar-andstorage/.

[70] T. M. Gur, "Review of electrical energy storage technologies, materials and systems: challenges and prospects for largescale grid storage," Energy \& Environmental Science, vol. 11, pp. 2696-2767, 2018.

[71] "Highview power," Cryogenic energy storagehttps://www .highviewpower.com/technology/.

[72] A. Poullikkas, "A comparative overview of large-scale battery systems for electricity storage," Renewable and Sustainable Energy Reviews, vol. 27, pp. 778-788, 2013.

[73] O. Achkari and A. El Fadar, "Renewable energy storage technologies - a review," in Conference Internationale en Automatique \& Traitement de Signal (ATS-2018), Proceedings of Engineering and Technology-PET, vol. 35pp. 69-79, Tangier, Morocco, 2018.

[74] J. Gao, Y. Wang, Y. Ping et al., "A thermodynamic analysis of methanation reactions of carbon oxides for the production of synthetic natural gas," RSC Advances, vol. 2, no. 6, pp. 23582368, 2012.

[75] A. Halls, "Lake Nasser fisheries: recommendations for management, including monitoring and stock assessment," Penang, Malaysia, WorldFish Program Report, 2015.

[76] Food and Agriculture Organization of the United Nations, 4. Aquaculture methods and practices: a selected reviewFAODecember 2020, http://www.fao.org/3/t8598e/t8598e05.htm.

[77] J. M. Njiru, C. M. Aura, and J. K. Okechi, "Cage fish culture in Lake Victoria: a boom or a disaster in waiting?," Fisheries Management and Ecology, vol. 26, pp. 426-434, 2018.

[78] O. A. Habib, M. Shehata, M. Zaki, H. Ammar, and S. H. Abdel Rahman, "Building fish enclosure in Lake Nasser," in Lake Nasser Development Authority, WorldFish Center technical manual no.1950, The WorldFish Center, Penang, Malaysia, 2009.

[79] F. Solar and E. Age, "Environmental benefits," December 2020, https://news.energysage.com/floating-solar-what-you-needto-know/.

[80] R. S. Spencer, J. Macknick, A. Aznar, A. Warren, and M. O. Reese, "Floating photovoltaic systems: assessing the technical potential of photovoltaic systems on man-made water bodies in the continental United States," Environmental Science \& Technology, vol. 53, pp. 1680-1689, 2019.

[81] M. A. E. Galdino and M. M. de Almeida Olivieri, "Some remarks about the deployment of floating PV systems in Brazil," Journal of Electrical Engineering, vol. 5, pp. 10-19, 2017.

[82] Asian Development Bank (ADB), "Floating solar energy project. Initial environmental and social examination report," in Project Number: 51327-001, Environmental Resources Management (ERM), Vietnam, 2018.

[83] S. Weckend, A. Wade, and G. Heath, "End-of-life management: solar photovoltaic panels," International Renewable Energy Agency (IRENA) and the International Energy Agency (IEA), Report Number: T12-06:2016, 2016. 